\title{
Length-weight relationship and condition factor for twelve fish species from the Igarapé Fortaleza basin, a small tributary of the Amazonas River estuary
}

\author{
Marcos Sidney Brito OLIVEIRA ${ }^{2}$ Luís Maurício Abdon SILVA ${ }^{2,3}$, Luiza PRESTES ${ }^{3,4}$, Marcos TAVARES-DIAS ${ }^{1,5 *}$ 巴D \\ Universidade Federal do Amapá (UNIFAP), Programa de Pós-Graduação em Biodiversidade Tropical, Macapá, Amapá, Brasil \\ 2 Instituto de Pesquisas Científicas e Tecnológicas do Estado do Amapá (IEPA), Núcleo de Pesquisas Aquáticas, Macapá, AP, Brasil \\ 3 Universidade do Estado do Amapá (UEAP), Macapá, AP, Brasil \\ ${ }^{4}$ Universidade Federal Rural da Amazônia (UFRA), Programa de Pós-Graduação Ecologia Aquática e Pesca (PPGEAP), Belém, PA, Brasil \\ Embrapa Amapá, Macapá, AP, Brasil \\ * Corresponding author: marcos.tavares@embrapa.br; (D) https://orcid.org/0000-0002-8376-1846
}

\begin{abstract}
Length and weight data are useful in fisheries management and standard results of fish monitoring programs. Length-weight relationship (LWR) is used for estimating the weight corresponding to a given length, and the condition factor is used to compare the body condition, fatness or health of fish populations. This study aimed to estimate the LWR and the condition factor for 12 freshwater fish species from the Igarapé Fortaleza basin, a tributary of the Amazonas River system in the State of Amapá, eastern Amazon (Brazil). The coefficient of determination, the allometric condition factor and the allometric coefficient varied among species, and were compared with populations elsewhere. In $83.3 \%$ of the species, the allometric coefficient remained within the expected range. This was the first record of LWR parameters for Acestrorhynchus falcirostris.
\end{abstract}

KEYWORDS: allometry, Brazil, freshwater fish, growth pattern

\section{Relação peso-comprimento e fator de condição para doze espécies de peixes da bacia do Igarapé Fortaleza, um pequeno tributário do estuário do Rio Amazonas}

\section{RESUMO}

Os dados de comprimento e peso são úteis na gestão da pesca e resultados padrão dos programas de monitoramento de peixes. A relação peso-comprimento (RPC) é usada para estimar o peso correspondente a um determinado comprimento e o fator de condição é usado para comparar a condição corporal, gordura ou saúde de populaçóes de peixes. O objetivo deste estudo foi estimar a RPC e o fator de condição para 12 espécies de peixes de água doce da bacia do Igarapé Fortaleza, um afluente do sistema do Rio Amazonas no estado do Amapá, na Amazônia oriental brasileira. O coeficiente de determinação, o fator de condição alométrico e o coeficiente alométrico variaram entre espécies, e foram comparados com populaçóes de outras localidades. Para 83,3\% das espécies, os valores do coeficiente alométrico estavam dentro da faixa esperada. Este foi o primeiro registro de parâmetros de RPC para Acestrorhynchus falcirostris.

PALAVRAS-CHAVE: alometria, Brasil, peixes de água doce, padrão de crescimento

Fish body length and body weight are two useful empirical measures in stock assessment and more generally, in population ecology, community and ecosystem ecology studies (Giarrizzo et al. 2015; Baitha et al. 2018). Fish growth is generally measured by the increase of length and weight, which are used to determine population development. The length-weight relationship (LWR) is a mathematic model that allows for the conversion of length into weight, and weight into length in stock assessment models, as well as the estimation of biomass from the length frequency distribution. LWR can be used to determine possible differences between separate stock units of a species, provided all units are studied with the same fully standardized sampling methodology (Dieb-Magalhães et al. 2015; Freitas et al. 2017; Baitha et al. 2018). LWR is also used for estimating the condition factor of fish, which is used to compare the health of fish populations. A high condition factor indicates that a fish is heavier than a fish of the same length with a lower condition factor, and thus always refers to a deviation from the average LWR for a population (Le Cren 1951; Froese 2006; Freitas et al. 2017). The analysis of LWR and condition factor of fish populations are important tools to support the rational management of fishing resources, and may help in the implementation of public policies (Dieb- 
Magalhães et al. 2015; Giarrizzo et al. 2015; Silva et al. 2015; Baitha et al. 2018). LWR studies for freshwater fish species from the Amazonas River basin have increased, providing important biological information on fish populations (e.g. Freitas et al. 2014; Silva et al. 2015; Giarrizzo et al. 2015; Cella-Ribeiro et al. 2015; Dieb-Magalhães et al. 2015; Freitas et al. 2017). However, there still are large gaps in the geographical coverage of biological data for many fish widely distributed in the Amazon basin.

The Igarapé Fortaleza basin is a $27.3-\mathrm{km}$ long tributary basin of the Amazonas River estuary in the eastern Amazon in Brazil, in the state of Amapá (municipalities of Santana and Macapá) (Figure 1). The Fortaleza basin has a large extension of floodplain areas, with very peculiar characteristics owed to the combined strong influence of the high rainfall of the Amazon region and the daily tides of the Amazonas River due to the proximity to the Atlantic Ocean (Takyama et al. 2004). These areas are important as shelter and feeding grounds for several fish species of different families, including Acestrorhynchidae, Cichlidae, Auchenipteridae, Callichthyidae, Curimatidae, Erythrinidae, Anostomidae and Triportheidae (Takyama et al. 2004; Gama and Halboth 2004). In this region, fisheries of several species belonging to these families are among the most important economic activities, and fish stocks are the main food source for many traditional communities. This study aimed to estimate LWR and the allometric condition factor for 12 fish species of different families from Igarapé Fortaleza, for which there is a lack of information on LWR.
The study was conducted monthly from March 2012 to December 2014. Samples of each fish species (juveniles and adults) (Table 1) were collected using gillnets ( $15 \mathrm{~m}$ long and $1.5 \mathrm{~m}$ deep) with different mesh sizes $(10,15,20,25,30,35$ and $40 \mathrm{~mm}$ between knots). Fish were sampled at six points in the southeastern sector of the Fortaleza basin (Figure 1). Mean duration of net exposure at each sampling point was six hours. All fish were transported in boxes with ice to the Laboratory of Aquaculture and Fishery at Embrapa Amapá, in Macapá, state of Amapá. In the laboratory, fish were measured for total length $(\mathrm{cm})$ and body weight $(\mathrm{g})$ for determination of LWR and the allometric condition factor. The study was authorized by the Ethics Committee on Animal Use of Embrapa Amapá (protocol \# 004 CEUA/CPAFAP) and by ICMBio (SISBIO license \# 23276-1).

LWR was calculated using the equation $\mathrm{W}=a \mathrm{TL}_{\mathrm{t}}^{b}$, where $\mathrm{W}$ is the total weight (in g) and TL is the total length (in $\mathrm{cm}$ ), while $a$ is constant and $b$ is the allometric coefficient. The values $a$ and $b$ were estimated by linear regression of the transformed equation: $\log \mathrm{W}=\log a+b \log \mathrm{TL}$, using the software Statistica, v. 7.0. Additionally, 95\% confidence limits (CL) of the $b$ coefficient and the coefficient of determination $\left(\mathrm{R}^{2}\right)$ of the LWR were estimated for each species. Outliers were graphically identified and removed (Froese and Binohlan 2000). Type of growth was determined through a t-test where: $\mathrm{H}_{0}: b=3$ (isometric growth) and $\mathrm{H}_{1}: \mathrm{b} \neq 3$ (allometric growth) (Zar 2010). The allometric condition factor $(\mathrm{K}$ was calculated according to equation $\mathrm{K}_{\mathrm{a}}=\mathrm{W} / \mathrm{L}_{\mathrm{t}}^{b}(\mathrm{Le}$ Cren 1951).

Table 1. Total body length and weight, length-weight relationship (LWR) parameters and allometric condition factor for samples of 12 fish species collected in the Igarapé Fortaleza basin, state of Amapá (Brazil) from March 2012 to December 2014.

\begin{tabular}{|c|c|c|c|c|c|c|c|c|c|}
\hline \multirow{2}{*}{ Order/Family/Species } & \multirow{2}{*}{$\mathrm{N}$} & \multicolumn{2}{|c|}{ Total length $(\mathrm{cm})$} & \multicolumn{2}{|c|}{ Body weight (g) } & \multicolumn{3}{|c|}{ LWR parameters } & \multirow{2}{*}{$\frac{\text { Cond factor }}{K_{a}}$} \\
\hline & & Min & Max & Min & Max & $a(95 \% \mathrm{CL})$ & $b(95 \% \mathrm{CL})$ & $R^{2}$ & \\
\hline \multicolumn{10}{|l|}{ CHARACIFORMES } \\
\hline \multicolumn{10}{|l|}{ Acestrorhynchidae } \\
\hline Acestrorhynchus falcirostris Cuvier, 1819 & 33 & 12.5 & 28.5 & 16.0 & 156.0 & $0.015(0.005-0.045)$ & $2.757(2.405-3.106)$ & 0.892 & $0.839 \pm 0.071$ \\
\hline \multicolumn{10}{|l|}{ Triportheidae } \\
\hline Triportheus angulatus Spix \& Agassiz, 1829 & 31 & 14.0 & 20.5 & 20.0 & 78.0 & $0.006(0.0008-0.047)$ & $3.136(2.419-3.852)$ & 0.734 & $0.867 \pm 0.052$ \\
\hline \multicolumn{10}{|l|}{ Curimatidae } \\
\hline Curimata cyprinoides Linnaeus, 1766 & 65 & 6.6 & 15.0 & 3.8 & 44.6 & $0.020(0.014-0.028)$ & $2.848(2.699-2.996)$ & 0.959 & $1.155 \pm 0.062$ \\
\hline \multicolumn{10}{|l|}{ Erythrinidae } \\
\hline Hoplias malabaricus Bloch, 1794 & 67 & 12.0 & 32.5 & 16.0 & 412.0 & $0.013(0.007-0.021)$ & $2.962(2.805-3.118)$ & 0.956 & $0.860 \pm 0.060$ \\
\hline \multicolumn{10}{|l|}{ Anostomidae } \\
\hline Leporinus friderici Bloch, 1794 & 50 & 10.0 & 25.5 & 14.0 & 240.0 & $0.022(0.016-0.031)$ & $2.827(2.711-2.943)$ & 0.980 & $1.069 \pm 0.070$ \\
\hline \multicolumn{10}{|l|}{ CICHLIFORMES } \\
\hline \multicolumn{10}{|l|}{ Cichlidae } \\
\hline Chaetobranchus flavescens Heckel, 1840 & 39 & 9.5 & 24.0 & 22.0 & 248.0 & $0.051(0.029-0.088)$ & $2.647(2.443-2.850)$ & 0.949 & $1.211 \pm 0.112$ \\
\hline Pterophyllum scalare Schultze, 1823 & 42 & 5.5 & 10.5 & 2.0 & 22.0 & $0.027(0.013-0.056)$ & $2.795(2.418-3.172)$ & 0.848 & $1.249 \pm 0.161$ \\
\hline Aequidens tetramerus Heckel, 1840 & 92 & 10.0 & 19.2 & 21.7 & 157.0 & $0.084(0.043-0.163)$ & $2.487(2.238-2.737)$ & 0.813 & $1.269 \pm 0.081$ \\
\hline \multicolumn{10}{|l|}{ SILURIFORMES } \\
\hline \multicolumn{10}{|l|}{ Auchenipteridae } \\
\hline Ageneiosus ucayalensis Castelnau, 1855 & 24 & 14.0 & 35.5 & 20.0 & 260.0 & $0.026(0.008-0.083)$ & $2.518(2.139-2.896)$ & 0.851 & $0.874 \pm 0.054$ \\
\hline Auchenipterus nuchalis Spix \& Agassiz, 1829 & 27 & 14.0 & 21.0 & 28.0 & 80.0 & $0.055(0.012-0.251)$ & $2.331(1.797-2.865)$ & 0.763 & $0.997 \pm 0.037$ \\
\hline Trachelyopterus galeatus Linnaeus, 1766 & 37 & 7.5 & 14.5 & 4.0 & 52.0 & $0.003(0.001-0.006)$ & $3.579(3.303-3.856)$ & 0.951 & $1.085 \pm 0.083$ \\
\hline \multicolumn{10}{|l|}{ Callichthyidae } \\
\hline Callichthys callichthys Linnaeus, 1758 & 38 & 15.5 & 21.0 & 58.0 & 140.0 & $0.040(0.008-0.203)$ & $2.709(2.143-3.275)$ & 0.723 & $1.102 \pm 0.041$ \\
\hline
\end{tabular}

$\mathrm{N}=$ sample size; Min = minimum; Max = maximum; $a=$ intercept; $b=$ slope; $\mathrm{R}^{2}=$ coefficient of determination of the length-weight relationship; $95 \% \mathrm{CL}=95 \%$ confidence interval; $\mathrm{K}_{\mathrm{a}}=$ allometric condition factor. 


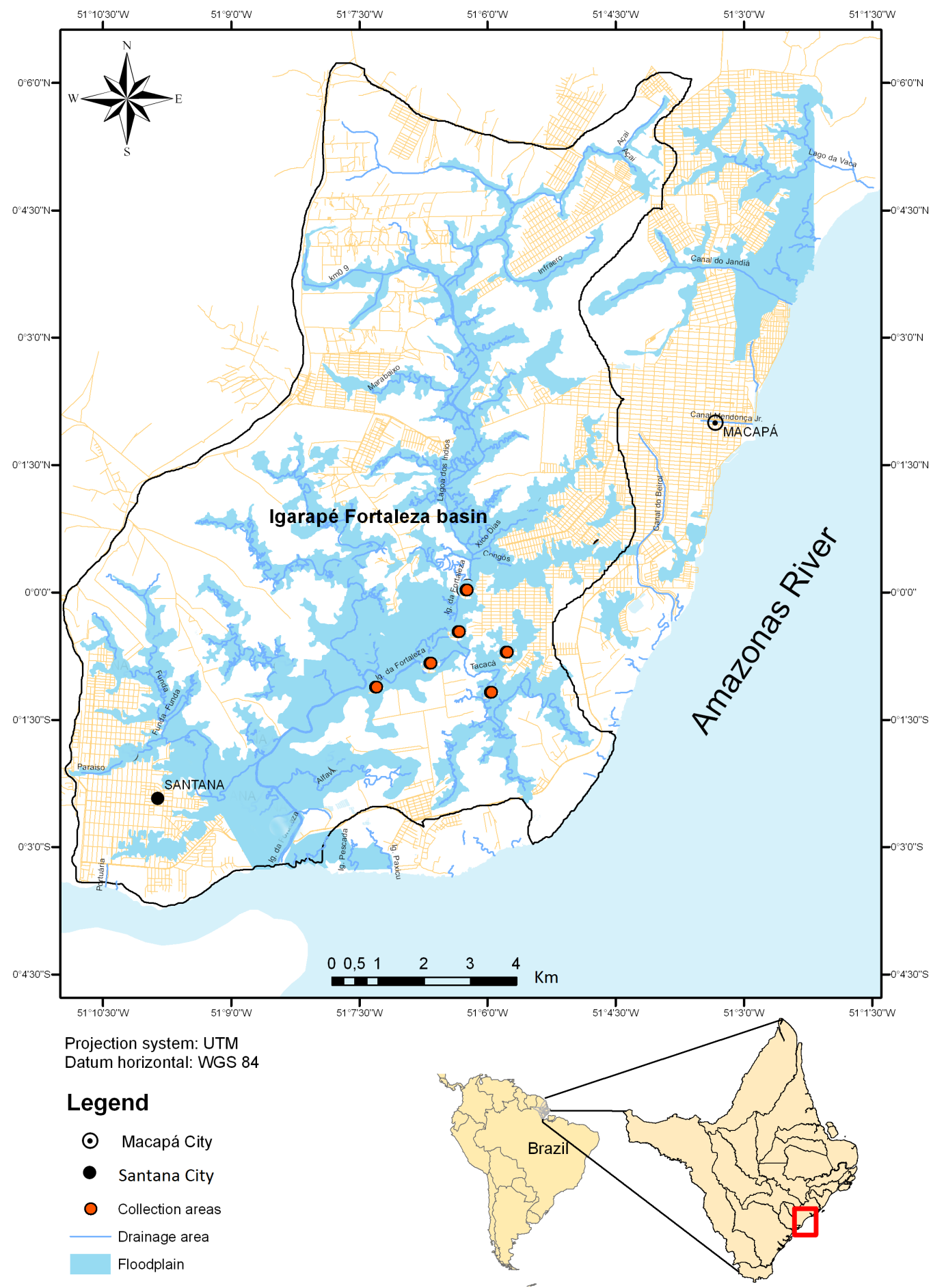

Figure 1. Map of the Amazonas River tributary basin of Igarapé Fortaleza, in the state of Amapá, in northern Brazil (small maps). Red dots indicate the fish sampling sites. This figure is in color in the electronic version.

Mean K ranged from 0.839 for Acestrorhynchus falcirostris to 1.211 for Chaetobranchus flavescens. The $b$ coefficient ranged from 2.331 for Auchenipterus nuchalis to 3.579 for Trachelyopterus galeatus. The $\mathrm{R}^{2}$ of the LWR ranged from 0.723 for Callichthys callichthys to 0.980 for Leporinus friderici (Table
1). $K_{2}$ was variable among species, probably reflecting recent feeding conditions, as well as physiological and/or reproductive state of the fish, as the proportions of males and females in the sample were different for each species (Le Cren 1951). Trachelyopterus galeatus and Triportheus angulatus showed 
positive allometric growth, while the remaining species showed negative allometric growth. Except for Aequidens tetramerus and A. nuchalis, which presented a $b$ coefficient below 2.5 , and $T$. galeatus with $b$ above 3.5 , the remaining species presented $b$ within the expected range of 2.5 - 3.5 (Froese 2006).

LWR parameters are available for various fish species at FishBase (www.fishbase.org), a global information system on fish (Froese and Pauly 2019). This is the first report of LWR for $A$. falcirostris. We found some contrasting values for the estimated parameters for the other species in other parts of their distribution range. Froese and Pauly (2019) inform mean $b$ coefficients of 3.180 for $A$. tetramerus in the Xingu River, 2.760 to 3.180 for C. callichthys and Curimata cyprinoides in the Tucuruí reservoir (Tocantins River.), 2.483 for $C$. flavescens and 3.071 for $T$. galeatus in the Madeira River, 2.807 for Pterophyllum scalare in the Matapi River in Brazil, 2.897 to 3.090 for T. angulatus and 2.655 to 3.130 for $L$. friderici from diverse localities in Brazil and French Guiana, 2.720 to 3.305 for Hoplias malabaricus from Brazil, Portugal, Peru, Argentina, Colombia and French Guiana, 2.755 to 3.055 for Ageneiosus ucayalensis and 2.750 to 3.136 for $A$. nuchalis from Brazil. The $b$ coefficient in our samples fell within the $95 \%$ confidence interval for the species (Table 1), except for A. tetramerus, $L$. friderici, A. ucayalensis and $A$. nuchalis.

These lower $b$ values for $A$. tetramerus and $A$. nuchalis and higher values for $T$. galeatus may be due to various factors. The growth type of fish species can be changeable, depending on the season, food availability, population, sex or physiology (Silva et al. 2015; Giarrizzo et al. 2015; Cella-Ribeiro et al. 2015; Dieb-Magalhães et al. 2015; Freitas et al. 2017). Therefore, more data, from a larger sample size, are needed to confirm these extreme growth pattern values.

No data for Igarapé Fortaleza are available in FishBase, therefore ours are likely the first LWR estimates for fish in the Fortaleza basin, contributing to the knowledge on the biology of fish stocks and efforts to achieve sustainable fishery in the basin. Furthermore, our results contribute to the improvement of fishery exploitation models in the Amazon.

\section{ACKNOWLEDGMENTS}

The authors acknowledge Conselho Nacional de Desenvolvimento Científico e Tecnológico (CNPq) for the productivity research grant awarded to M. Tavares-Dias (\# 303013/2015-0).

\section{REFERENCES}

Baitha, R.; Sinha, A.; Koushlesh, S.K.; Chanu, T.N.; Kumari, K.; Gogoi, P.; Ramteke, M.H.; Borah, S.; Das, B.K. 2018. Length-weight relationship of ten indigenous freshwater fish species from Gandak River, Bihar, India. Journal of Applied Ichthyology, 34: 233-236.
Cella-Ribeiro, A.; Hauser, M.; Nogueira, L.D.; Doria, C.R.C.; Torrente-Vilara, G. 2015. Length-weight relationships of fish from Madeira River, Brazilian Amazon, before the construction of hydropower plants. Journal of Applied Ichthyology, 31: 939-945

Dieb-Magalhães, L.; Florentino, A.C.; Soares, M.G.M. 2015. Length-weight relationships and length at first maturity for nine fish species of floodplain lakes in Central Amazon (Amazon basin, Brazil). Journal of Applied Ichthyology, 31: 1182-1184.

Freitas, T.M.S.; Prudente, B.S.; Fontoura, N.F.; Montag, L.F.A. 2014. Length-weight relationships of dominant fish species from Caxiuaña National Forest, eastern Amazon, Brazil. Journal of Applied Ichthyology, 30: 1081-1083.

Freitas, T.M.S.; Prudente, B.S.; Montag, L.F.A. 2017. Length-weight relationship in ten fish species from the Nhamundá River, the Amazon Basin, Brazil. Acta Amazonica, 47: 75-78.

Froese, R. 2006. Cube law, condition factor and weight-length relationships: history, meta-analysis and recommendations. Journal of Applied Ichthyology, 22: 241-253.

Froese, R.; Binohlan, C. 2000. Empirical relationships to estimate asymptotic length, length at first maturity and length at maximum yield per recruit in fishes, with a simple method to evaluate length frequency data. Journal of Fish Biology, 56: 758-773.

Froese, R.; Pauly, D. 2019. FishBase. (https://www.fishbase.org). Accessed on 01/02/2019.

Gama, C.S.; Halboth, D.A. 2004. Ictiofauna das ressacas das bacias do Igarapé da Fortaleza e do Rio Curiaú. In: Takiyama, L.R.; Silva, A.Q. (Org.). Diagnóstico das Ressacas do Estado do Amapá: Bacias do Igarapé da Fortaleza e Rio Curiaú, Macapá-AP. CPAQ/ IEPA and DGEO/SEMA, p.23-52.

Giarrizzo, T.; Oliveira, R.R.S.; Andrade, M.C.; Gonçalves, A.P.; Barbosa, T.A.P.; Martins, A.R.; Marques, D.K.; Santos, J.L.B.; Frois, R.P.S.; Albuquerque, T.P.O.; Montag, L.F.A.; Camargo, M.; Sousa, LM. 2015. Length-weight and length-length relationships for 135 fish species from the Xingu River (Amazon basin, Brazil). Journal of Applied Ichthyology, 31: 514-424.

Le Cren, E.D. 1951. The length-weight relationship and seasonal cycle in gonadal weight and condition in the perch (Perca fluviatilis). Journal of Animal Ecology, 20: 201-219.

Silva, L.M.A.; Oliveira, M.S.B.; Florentino, A.C.; Tavares-Dias, M. 2015. Length-weight relationship of 11 fish species from a tributary of the Amazon River system in northern Brazil. Journal of Applied Ichthyology, 31: 816-817.

Takyama, L.R.; Silva, A.Q.; Costa, W.J.P.; Nascimento, H.S. 2004. Qualidade das águas das ressacas das bacias do Igarapé da Fortaleza e do Rio Curiaú. In: Takiyama L.R.; Silva, A.Q. (Eds.). Diagnóstico das ressacas do estado do Amapá: bacias do Igarapé da Fortaleza e Rio Curiaú, Macapá-AP. CPAQ/ IEPA and DGEO/SEMA, p.81-104.

Zar, J.H. 2010. Biostatistical Analysis. Prentice-Hall, London, 944p.

RECEIVED: $19 / 02 / 2019$

ACCEPTED: 30/12/2019

ASSOCIATE EDITOR: Helder M. Espírito Santo 